\title{
Water Works in India
}

\author{
Roopali Phadke ${ }^{1}$ \\ Macalester College, USA
}

\begin{abstract}
Most mornings, the line begins to form at dawn: scores of silent women with babies strapped to their backs, buckets balanced on their heads, and in each hand a bright-blue plastic jug. On good days, they will wait less than an hour before a water tanker rumbles across the rutted dirt path that passes for a road in Kesum Purbahari, a slum on the southern edge of New Delhi. On bad days, when there is no electricity for the pumps, the tankers don't come at all. "That water kills people," a young mother named Shoba said one recent Saturday morning, pointing to a row of battered pails filled with thick, caramel-colored liquid. "Whoever drinks it will die."
\end{abstract} (Specter 2006: 61)

\section{Introduction}

In an October 2006 New Yorker article, titled "The Last Drop", Michael Specter provided the above portrait of water deprivation in India. In the same month, the New York Times published a series of articles depicting the alternate crises of deluge and drought that produce water insecurity and vulnerability in India. The first of the three pieces that appeared in the New York Times, titled the "Thirsty Giant", interviewed Sunita Narain, Director of the Centre for Science and the Environment in New Delhi, about the importance of water resources in India. Narain stated that "If we become rich or poor as a nation, it's because of water" (Sengupta 2006).

Like many parts of the developing world, India's water problems have long been portrayed by the international media as crises of poverty, desperation and corruption. The water crisis discourse is dominated by visions of a world quickly running out of fresh water. Drawing an analogy to the "peak oil" discourse, "peak water" adherents express an impending dystopia through images of over-pumped aquifers in the world's breadbasket regions, excessive irrigation that is rapidly depleting rivers and deltas, neglected pollutants that are poisoning return water flows, and crumbling urban water infrastructures (Gleick 2009). Climate change scenarios paint an even bleaker picture for those in already drought-prone or flood-prone regions.

In response to this dystopia, a transnational policy network emerged in the last ten to fifteen years, and included institutions such as the World Water Council and the Global Water Partnership. Michael Goldman has argued that this network has succeeded in promoting a narrative that frames water poverty and insecurity as the result of "inefficient and politicized governments that treat water as if it were a free natural resource." (2005: 242). This discourse argues that the solutions to global water insecurities lie in the privatization of infrastructure and services so that international firms, aid agencies and water institutions can pave the way for "real" market pricing to improve allocation and conservation decisions.

This focus on global water scarcities and global water solutions overshadows the real gains in water governance that have been achieved at local and regional scales in the absence of massive international development aid and private sector investments. This is particularly true in India, where over the last three decades watershed development has significantly matured as a concept, method and technology for improving livelihoods. While some of this work has been funded by international philanthropy, the bulk of these investments have come from state agencies and local citizens. Echoing the introductory article of this special section, these everyday initiatives 'in the middle' have helped transform the lives of people and communities.

This article begins by setting the context for water sector planning in India, highlighting the conventional academic response to the failed water infrastructure models of the past, and summarizing the slate of alternative proposals. Next, the article describes a set of empirical cases from the Indian state of Maharashtra where a social movement is tackling the most vexing issues faced by watershed planners: equity and landlessness. The final section discusses the ways in which this article resonates with the other case studies in this special section, and advances the concept of Ecologies of Hope (Rajan and Duncan 2013).

${ }^{1}$ Dr. Roopali Phadke, Associate Professor, Department of Environmental Studies, Macalester College, St. Paul, MN 55105, USA. Phadke "at" macalester.edu. Many thanks to Ravi Rajan and Colin Duncan for their stewardship of this special issue, and to all the participants of the Ecologies of Hope writing group for their support. This is the second paper in Rajan S.R. and Duncan C.A.M. (eds.) "Ecologies of Hope", special section of the Journal of Political Ecology 20: 70 179. 


\section{The context}

As the New Yorker and New York Times articles referenced in the introduction of this article suggest, Indian water politics have been driven by powerfully articulated perceptions of dystopia based on scarcity. For nearly two centuries in India, the conventional engineering paradigm has maintained that large-scale infrastructure development was the means for improving agricultural productivity and resolving water scarcities. This "gigantism" approach created massive dams and canal systems aimed at transferring water across thousands of miles from one basin into another. These infrastructure projects also included extensive networks of weirs, tunnels, pipelines, hydroelectric plants and transformer stations. As Lyla Mehta has argued, the gigantism approach to infrastructure naturalized water scarcity as a chronic physical condition rather than a complex natural, economic and socio-cultural phenomenon. As a result, state investments focused on building the technological systems that would eradicate scarcity rather than understanding the relational and distributional aspects of water scarcity that reflect prevailing social and power relations (Mehta 2005:4).

Over the last thirty years, environmental scholars and activists have aimed to dislodge the planning model that equated real and constructed water security with giant infrastructure. A large body of literature spans a range of themes and periods in Indian water development planning, including historiographies of pre-colonial water harvesting efforts and colonial water regimes (Agarwal and Narain 1997; Gilmartin 1994; Headrick 1988; Whitcombe 1972; Mosse 2003), collective action and the study of common property resources (Rangan 2000; Mollinga 2000; Wade 1988), gender based analyses (van Koppen 2000; MeizenDick and Zwarteveen 1998; Ramamurthy 1997), studies of new social movements contesting dam development (Mehta 2005; Baviskar 1995; Thukral 1992), and studies of the cultural politics of water as a natural resource (Baviskar 2007).

Given this immense body of work, the release of the 2000 World Commission on Dams country study on India was met with great interest within environmental activist and scholarly communities. This 280 page report, authored by a dozen leading water scholars in India, reviewed the record of large-scale dam and irrigation development in the country. The authors concluded that a century or more of large-scale water development had resulted in major ecological and social impacts, including massive human displacement, soil erosion, and extensive waterlogging. They also reported that these projects, often built in the name of famine protection, had achieved limited food security benefits. The India country study stated that the marginal contribution of large dams to increased foodgrain production had been less than 10 percent in India since the post-independence period (Rangachari et al. 2000: 27).

As the product of an independent, international and multi-stakeholder commission, the World Commission on Dams report brought a sense of political legitimacy and authority to the claims that Indian activists and academics have been asserting for decades. The report also lent credibility to the anti-dam movements that have been leveling a strong critique against the central and state governments for pursuing a model of water development that favored the centralization of water and power, and neglected the needs of India's most marginalized peoples (Mosse 2003). The report also acknowledged that the debate is misrepresented as a contest between large versus small projects. Instead they argue that the challenge for water development in India is to design spatially integrated yet politically decentralized infrastructure (Rangachari et al. 2000: 16). Promoting watershed planning is seen as key to achieving this goal, especially in arid regions that are dominated by rain-fed agriculture.

The Centre for Science and Environment in New Delhi is an NGO that has played an important role in the reform of water infrastructure planning. First led by Anil Agarwal, one of India's most noted environmental activist-scholars, the Centre's water campaigns have aimed at resurrecting India's water harvesting traditions. Their efforts culminated in the 1997 volume Dying Wisdom, a 400 page volume edited by Sunita Narain and Anil Agarwal that documented rainwater harvesting traditions and revitalization efforts in fifteen geographic regions in India (Agarwal and Narain 2007). A decade after the publication of Dying Wisdom, the Centre's water efforts now span a journal, an international activist network (Waterharvesters), annual water pilgrimages and training seminars (pani yatras), an extensive online information clearinghouse, and a national database on urban and rural water harvesting structures.

Many other institutions have played a longstanding role in government water reforms at the central, state and district levels. This includes the work of the People's Science Institute from Dehradun in Uttarakahnd, the Watershed Organization Trust (WOTR) in Maharashtra, the Mysore Rural Development Agency in Karnataka, and Tarun Bharat Sangh in Rajasthan. The Forum for Watershed Research and Policy Dialogue (ForWaRD) is one of the newest players in this field. This collaborative effort connects the work of the Society for Promoting Participative Ecosystem Management (SOPPECOM) in Pune, the Gujarat Institute of Development Research (GIDR) in Ahmedabad and the Centre for Interdisciplinary Studies in Environment and Development (CISED) in Bangalore. Among their many projects, the collaborative aims to build a comprehensive public domain and GIS-linked database of all completed and ongoing watershed development efforts in India.

The conventional response from NGOs has focused on increasing local participation in planning and implementation, decentralizing project administration and reducing water and electricity subsidies (Moench 
et al. 1999: 5). In addition to NGO voices, the impetus for reform has also come from bilateral aid agencies and international financial institutions who insist watershed development is best pursued through a sustainable livelihoods paradigm. The sustainable livelihoods model, popularized by Robert Chambers and Gordon Conway in the mid-1990s, asserted a development framework for understanding the complexities of poverty by focusing on the natural, social and economic assets of households and communities. A livelihood is considered "sustainable" when it can cope with and recover from stresses and shocks and maintain or enhance capabilities and assets, while not undermining the natural resource base. In the case of watershed development, sustainable livelihood creation is premised on securing social and economic rights alongside access to clean water supplies (Chambers and Conway 1991).

With so many different stakeholders interested in promoting development reforms, watershed planning has also become an important test for devolving power from state agencies toward local organizations. Implementing new approaches toward water development has therefore brought to the fore some intractable governance issues. While the technical challenges involved with implementing soil and water conservation have largely been resolved, addressing sustainable livelihoods remains a vexing issue. The following section chronicles the rise of interest in watershed planning and describes how these challenges are being addressed.

\section{Watershed planning and its challenges}

While NGO-led watershed development is celebrated today in India, the first watershed planning efforts predate the rise of NGO activism in the 1980s. The Government of India itself led this effort in the 1970s upon realization that the "Green Revolution," that was starting to transform agriculture in the regions of Punjab and Haryana through the application of irrigation and chemical inputs, had done little to benefit the sectors of society that depended on rain-fed agriculture. Despite heavy investments in dams and vast irrigation networks, two thirds of India's farmlands continue to be un-irrigated and classified as rain-fed. The neglect of rain-fed lands, and of the inextricable link between the degradation of rain-fed lands and the poverty of large numbers of people in India, supported a shift in agricultural policy toward watershed planning (Turton, Warner and Groom 1998: 1). In contrast to conventional water resources development, which was top-down, centralized, and industrial in nature, watershed planning was initially conceived and promoted by state planners as a means of catalyzing "bottom up" development. Watershed planning promised to simultaneously address land productivity, environmental sustainability and social equity for semi-arid and rain-fed agricultural zones.

The technical aspects of watershed development involve conserving soil moisture to support crop growth, capturing water in small ponds, tanks and dams, and promoting water infiltration to recharge aquifers. The most important step is to protect the upper reaches of the watershed so that water storage can be increased downstream. However, limiting water and land use in the upstream reaches of a basin often creates acute livelihood impacts because these lands are often held by the poorest and most marginal members of a rural community.

While rural development is the main objective driving watershed planning today, the earliest watershed planning efforts in India in the 1950s framed vulnerability and scarcity only in physical terms. Watershed planning was primarily oriented toward reducing rapid run-off and premature siltation of reservoirs in medium to large river valleys (Farrington et al. 1999). These conservation initiatives emanated from trials and experiments at research stations without significant farmer participation (Kerr et al. 2002: 76). These efforts also did not, for the most part, connect watershed rehabilitation or protection with socioeconomic livelihood concerns.

Beginning in the 1970s, a series of government programs attempted to implement the ideals of "integrated" watershed development. Integrated development referred to the goal of meeting both environmental and socio-economic goals simultaneously. In 1973, a significant effort to address the longterm issue of drought prevention and drylands farming was approached through the central government's Planning Commission Task Force on Integrated Agricultural Development in Drought Prone Areas. The Task Force suggested a strategy that combined soil and water conservation measures, afforestation, irrigation development, livestock development and the restructuring of cropping patterns. The Drought Prone Areas Program (DPAP) emerged as a result of these suggestions. While the DPAP now covers 69 districts in 13 states in India, the program has received limited funds compared to those expended on irrigation development.

Despite these efforts, there was an overwhelming sense of disappointment with the achievements of watershed development in its first twenty years because of a top down, inflexible technology approach and lack of interest in the local institutional prerequisites of watershed development (Kerr 2002b: 1390). The Seventh Five Year Plan attempted to address these problems by establishing CAPART (the Council for Advancement of People's Action and Rural Technologies) in 1986 to identify and channel money to NGOs for watershed project implementation. The National Watershed Development Programme for Rain-fed Areas (NWDPRA) was launched in 1990 to increase crop productivity in the poorest regions of rain-fed agriculture in the country. 
The most profound changes in watershed planning, however, came as a result of the 1994 Government of India Guidelines on Watershed Development. In 1993, after twenty years of ineffective drought mitigation and anti-poverty efforts, the Government of India convened a Commission to re-evaluate the state-led approach. Based on this committee's findings, the Ministry of Rural Development approved the 1994 guidelines on Watershed Development. These new guidelines focused on micro-watershed development and integrated rural development, including an important role for NGOs and local villagers in the project implementation process. Whereas earlier watershed protection efforts focused on the scale of a river valley, micro-watersheds were defined under the 1994 guidelines as areas encompassing between 500-1,000 hectares of land (Farrington et al. 1999: 7). The new guidelines responded to the need for more careful consideration of the social, financial and institutional issues surrounding the sustainability of watershed development efforts (Seeley et al. 2000). According to agricultural economist John Kerr, the 1994 guidelines were "revolutionary in the extent to which they devolved power, promoted indigenous technology and created a role for NGOs" (Kerr 2002b: 1391).

The National Watershed Development Programme for Rain-fed Areas was the first among government agencies to adopt the 1994 Guidelines. In 1999, A.N. Sarkar, the Commissioner of the Programme, announced that over the next 25 years his agency would aim to bring a total of 64 million hectares under watershed development. This was a formidable task because by 1999 only 16.5 million hectares had been developed (Srivastava and Chundi 1999: 13).

Vania and Taneja suggest that the 1994 guidelines must be seen in the context of a range of efforts aimed at institutionalizing participation in the 1990s, including Joint Forestry program efforts (2004: 29). The joint forestry management strategy created cooperative and "dialogic" relationships between Forestry Departments and adjacent village communities aimed at jointly and democratically protecting and managing forest land (Jeffery and Sundar 1999; Sivaramakrishnan 2002: 281). As of March 2006, the Indian Ministry of Environment and Forests reported that 106,482 committees were co-managing an area of about 22 million hectares in 28 States and the Union Territory of Andaman \& Nicobar (Pai and Datta 2006: 1).

In 2006, the report of the Technical Committee on Watershed Development in India comprehensively updated the 1994 Guidelines. The authors explicitly placed watershed development within the framework of sustainable livelihoods creation. They emphasized the need for greater participation, transparency and equity in program implementation. In their words, "We see the watershed action plan as neither a romanticisation of people's knowledge nor the debunking of the expert, rather a process of demystification of expertise in the process of valorizing popular understanding, through a creative dialogue between the two" (Technical Committee: 2006: 6). The report prescribed additional government allocations for watershed development in the amount of Rs. 10,000 crores (approximately US\$2.2 billion) per year for the next 15 years to cover 125 million hectares of land (Technical Committee: 2006: 19).

As it has evolved, the watershed concept has come to embody a wide range of champions, technologies, policies, and institutions. The challenges involved in simultaneously meeting the ecological, economic and social goals of watershed development exist because there is a broad set of variables that must be negotiated to establish a sustainable program. Table 1 lists the range of considerations involved in planning the technical, social and institutional components of a project. For example, the spatial scale of a watershed project, whether it is a micro-village or district project, must be matched with the most appropriate technical solutions. The social goals of the project must align with the spatial scale and technical options. Finally, there are a range of institutional concerns that impact project administration. For example, will the project be financed entirely by NGOs, as a NGO-government collaboration or as an international foundation project? These institutional parameters determine timeframes for implementation, channels of financing and the transparency of monitoring and evaluation.

The 2006 report of the Technical Committee on Watershed Development in India also noted that while national agencies such as CAPART and NWDPRA administer funds across India for watershed development, there is significant variation in project function and scope depending on the specific geographical features of the region. In the southern state of Tamil Nadu, for example, watershed development mainly takes the form of community water tank rehabilitation (Mosse 2003). In contrast, in the desert state of Rajasthan, rainwater harvesting primarily involves small dugout ponds called johads (UN-Interagency Working Group 1998). Social challenges can also be geographically unique. In regions where water conservation works best by storing water in underground aquifers, watershed projects must rely on farmers refraining from over-use of groundwater sources (Kerr 2002b: 1392). 
Physical resources: Ground, Surface, Conjoint

Operative scale: Micro-watershed, Village, District, and/or River basin

Technical options: Well/Tank, Surface irrigation, Small dam, Reforestation, Soil conservation

Socio-economic concerns: Women's participation, Access for Landless, Upstream-Downstream equity, Access to common lands

Reform principles: Decentralization, Deregulation, Community contributions (money and labor), Accountability, Transparency, Privatization

Institutional stakeholders: Government (local or national), NGO, Bilateral aid agency, Multilateral bank (e..g World Bank), Philanthropy

Table 1: Project options and planning complexities.

The 2006 report also noted that watershed development programs have achieved unequal success across India's 28 states. The states of Haryana, Rajasthan, Karnataka, Andhra Pradesh and Maharashtra are clearly leading the way. In the northern state of Haryana, the watershed results of the Sukhomajri project are almost legendary. Beginning in the mid 1970s, government officials joined forces with NGOs to implement a new water rights model whereby villagers have contractual agreements with the local government to share water on principles of equal access (Chopra 1990). The Mysore Rural Development Agency (MYRADA), a NGO based in the western state of Karnataka, has developed 58 micro-watersheds. Their programs focus on fostering community participation in the planning, budgeting and implementing of treatment measures to increase land productivity. The agency has also developed 100 self-help groups, of which 58 are comprised of women, scheduled castes and tribal peoples (Fernandez 1999). In the western arid state of Rajasthan, the work of NGO Tarun Bharat Sangh has had profound economic and hydrological impacts on communities in five districts. Their projects have challenged local governments to erect water tanks and dugout ponds to address an urgent groundwater crisis. These water conservation efforts have raised the water table in wells in project areas on average from 200 feet to 20 feet (Sharma 2002). According to researchers from the International Water Management Institute, land values in Tarun Bharat Sangh project areas have increased on average since 1985 from US\$2,000-2,400 per hectare to US\$ 9,000-10,000 per hectare (Shah and Raju 2001). Lastly, officials in the state of Andhra Pradesh have lead watershed development reforms by taking advantage of immense financial allocations under the new 1994 guidelines. Projects have been implemented in 9,000 watersheds at a cost of US\$ 45 million (Reddy et al. 2004: 298).

While it is difficult to generalize across all models of watershed development at work in the country, the empirical evidence suggests that most projects have been effective at raising soil moisture and water tables. Fewer projects, however, have met their social criteria for increasing equity and income, particularly for the landless. This is the conclusion John Kerr, Ganesh Pangare and Vasudha Lokur Pangare reached in their assessment of 86 projects in Maharashtra and Andhra Pradesh (Kerr et al. 2002). Their sample included a range of implementing organizations, including NGO-government partnerships, and addressed a spectrum of indicators, such as the promotion of collective action and the building or strengthening of social institutions. Kerr and his colleagues concluded that while participatory projects were producing more favorable results than technocratic blue-print approaches, equity related problems were still pervasive. In particular, they found that watershed projects are leaving women and the landless worse off by limiting their access to fuelwood (Kerr et al. 2002: 76).

The growing literature on watershed development supports their conclusions. Since integrated watershed development efforts began in the mid 1970s, gross agricultural yields and incomes have increased. Yet, it is also clear that benefits have largely accrued to the landed people, while landless, scheduled castes, and tribal people remain marginalized (Ninan et al. 1998: 3). One of the main hurdles in implementing watershed development is that users within even a micro-watershed are trying to meet different, and often, conflicting needs. Water is necessary for crop irrigation, domestic uses and fodder. For example, irrigation in the downstream reaches relies on water conservation in the upper catchment. This often requires that access to common lands be restricted in the upstream areas of a watershed basin. According to John Kerr, protection of upper catchment regions often comes at the expense of landless people whose livelihoods rely heavily on these areas (Kerr 2001: 1229). The common lands problem is so intractable that many NGOs avoid it altogether. Kerr reported that while three fourths of all villages in Maharashtra have common lands, two thirds of NGO watershed projects in Maharashtra are in villages with none (Kerr 2002a: 63). 
Watershed development has also placed a disproportional burden on women. While male farmers come forward to participate most often, women often perform most of the labor and tasks associated with participatory development. The 1995 Government Guidelines indicate that at least one woman must be a member of the official watershed committee. Seeley et al. have demonstrated how this has produced "quota women" who fill numbers but are marginalized in decision-making (2000: 8). They argue that this marginalization stems from participation efforts aimed at including "landowner" voices in societies where women do not customarily have title to land. Seeley et al. argue that the following issues must be incorporated into project design and implementation to better serve women's interests:

- $\quad$ Equal representation with men on watershed committees

- Equal wages for construction and other work

- $\quad$ Technical and social support to participate (including child care)

- $\quad$ Sensitizing government and NGO officials to women's roles

- $\quad$ Establishing monitoring systems to assess how women participate

- $\quad$ Creating linkages between self-help groups and watershed committees

Critiques of watershed development also point to how celebrations of project success often present an "organic vision of the village as a 'community' undifferentiated by hierarchies of power" (Baviskar 2007: 293). For example, Vasudha Chhotray has argued that villages in Andra Pradesh are often chosen for watershed development if they demonstrate a pre-project sense of "social harmony" (Chhotray 2004: 338). In her example, the National Watershed Development Program in Kurnool district purposefully works in villages that seem to be devoid of political factions. Chhotray argues that this program depoliticizes watershed development by either steering clear of local politics altogether or accommodating local politics to secure a false sense of unanimity or cooperation. In either case, Chhotray has argued that the outcome has been to "negate politics" and represent participation as a structured "itemized protocol" (ibid: 343). In a similar vein, Amita Baviskar, recounting the "spectacles and showplaces" that have surrounded the promotion of the watershed mission in Jhabua, Madya Pradesh, has argued that the "imperatives of rule supersede the technical guidelines of watershed management" when state programs choose to invest in those villages that represent the greatest possibility for project success through what she terms "manufactured consent" (Baviskar 1995: 291).

The issue of depolitization arises acutely in the case of the landless, because watershed development has largely worked by connecting land rights to water rights. For example, the Karnataka based NGO MYRADA, with its exemplary record at achieving results in watersheds, chooses not to directly accommodate landless peoples in their projects. In the MYRADA case, watershed development planners focus only on villages where less than 10 percent of the population is landless so as to ease conflict. Yet, the relationship between access to land and access to water cannot be taken for granted nor left unaddressed. Promoting greater equity is a fundamental principle of sustainable watershed development.

Sustainability also depends on capacity building within NGOs and creating collaborative relationships between NGOs, farmers groups and government officials that extend beyond individual projects. In their 1993 publication, Bhat and Satish cite many challenges related to instilling cooperation. They include the need to keep senior staff continuously employed, which lessens the need for NGOs to invest time and money in re-establishing connections. Vania and Taneja also point out that watershed sustainability requires dealing with the process problem of "scaling up" not just becoming "large-scale". They contend that while being "large-scale" means that watershed development efforts stretch across a wider geographical area, real "scaling up" happens through a deepening of social impacts, including addressing resource ownership and gender relations (Vania and Taneja 2004: 106).

As this brief historical review has suggested, enormous fiscal and intellectual resources have been invested in watershed development efforts in India over the last thirty years. Watershed projects and programs have been financed by government ministries, NGOs, multilateral/bilateral aid agencies and philanthropic foundations. In 1998, Turton et al. reported that over 800 NGOs were involved in implementing wasteland and watershed development efforts in India. By 2004, watershed development expenditures in India had amounted to over US\$ 1 billion annually (Reddy et al. 2004: 322).

While watershed development has fallen short of meeting the full range of integrated rural development goals, there have been tangible and scalable results that simply cannot be ignored. The Indian watershed planning experience has particularly been successful at articulating regional models that coalesce social movement actors, NGO technical experts and state officials in an intricate web of ideas and actions. Far from representing green utopias, these efforts illustrate how watershed development requires sustained political mobilization, great technological imagination and an understanding of nuanced agro-ecologies. In the following section I describe one such regional experience: the water equity movement in the western state of Maharashtra. Through the comparative analysis of three key NGO cases, I describe how social movement leaders have addressed equity and landlessness concerns. 


\section{The case}

Watershed development has a unique flavor in the state of Maharashtra, India's third largest and most populous state. As Figure 1 depicts, Maharashtra's topography is marked by two major relief divisions: the Konkan coastal strip which abuts the Arabian Sea, and the Deccan Plateau. While the Konkan region is known for its lush tropical climate and vegetation, the Deccan Plateau is characterized by chronic drought. During the colonial period, the region was administratively known as the "Deccan famine zone" where the unpredictability of precipitation meant that traditional agriculture was often considered a "gamble in the rains" (Attwood 1992: 22). Beginning with the organization of the first Irrigation Department in 1862 during the British colonial period, massive dam and canal systems have dramatically altered the landscape of this region. Maharashtra, in fact, has built the most dams and miles of canals of any state in India. In addition to its 1,229 existing large dams, at the turn of the $21^{\text {st }}$ century, irrigation planners had another 300 under construction in the state (Rangachari et al. 2000: 29).

Despite over one hundred years of monumental expenditures in physical infrastructure, the intensively irrigated regions of the state account for less than 15 percent of irrigable land. In contrast, 60 percent of cultivated lands remain in the vulnerable category of "rain-fed". It is this fact that connects the three case studies addressed in this article. Beginning in the 1970s, NGOs and farmers' organizations rallied against the continued incidence of severe drought and lack of state investment in rain-fed agriculture. This response was not based on political rhetoric alone. Instead, for the last thirty years, Maharashtrian NGOs have been experimenting with watershed models that aim to relieve drought conditions by empowering villagers to design and construct projects based on principles of social equity and environmental sustainability.

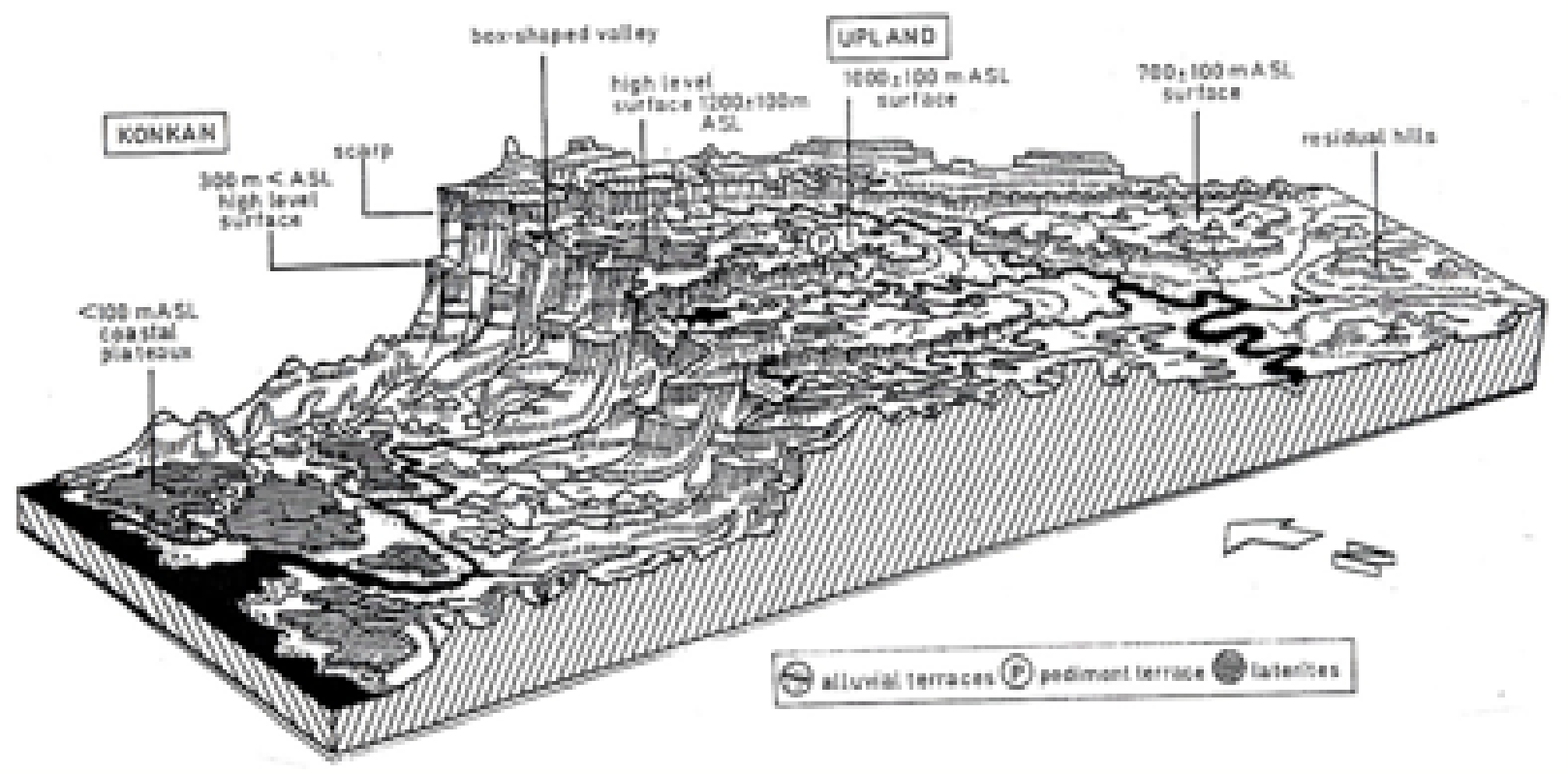

Figure 1: Coastal and upland river basins in Maharashtra. Source: Kale and Rajaguru, 1988.

Three initiatives have been milestones in arguing that watershed development and irrigation infrastructure can promote sustainable livelihoods in rural Maharashtra: Pani Panchayat, Ralegaon Siddhi and the Baliraja dam. The location of these three projects is depicted in Figure 2.

While each individual case has been analyzed by many activists and scholars, the three projects have not been comparatively examined. A comparative analysis reveals important linkages between people and ideas. In addition, a set of salient social and technical design principles emerges when outcomes are measured against one another. Table 2 provides the categories that have been used for drawing comparisons across the programs. The case study descriptions that follow explain how these outcomes have been realized.

\section{Pani Panchayat}

Across Asia, activist and academic writings have recognized Pani Panchayat efforts as an innovative and effective approach for sharing common pool resources (Pangare 1996; Khor and Lin 2002; Marothia 2002). Vilasrao and Kalpana Salunkhe established the Pani Panchayat (water council) program in the 1970s 
around the belief that farmers can engage in the collective management and equitable distribution of irrigation water in drought prone regions. The Pani Panchayat model began with their efforts at combating drought in Naigon village in Purandhar taluka of Pune district. This district lies within the Deccan Plateau just east of the Sahyadri mountain range. The district is characterized by semi-arid conditions with an average annual rainfall of 600-700 millimeters.

Vilasrao Salunkhe began his career as an industrial engineer. Upon graduating from the University of Pune in 1960, he founded a small tools manufacturing company called "Accurate Engineering." His business success led to his appointment in 1972 as the Chairman of the Western Maharashtra Development Corporation. During years of terrible drought in the early 1970s, Salunkhe toured the rural parts of the state and made a decision to experiment with alternative approaches to irrigation development. It was out of these experiences that he and his wife founded the Gram Gaurav Pratisthan (GGP) in 1974 as a NGO trust to pursue drought relief activities in Purandhar. Kalpana Salunkhe's expertise in horticulture and botany complemented Vilasrao's technical training.

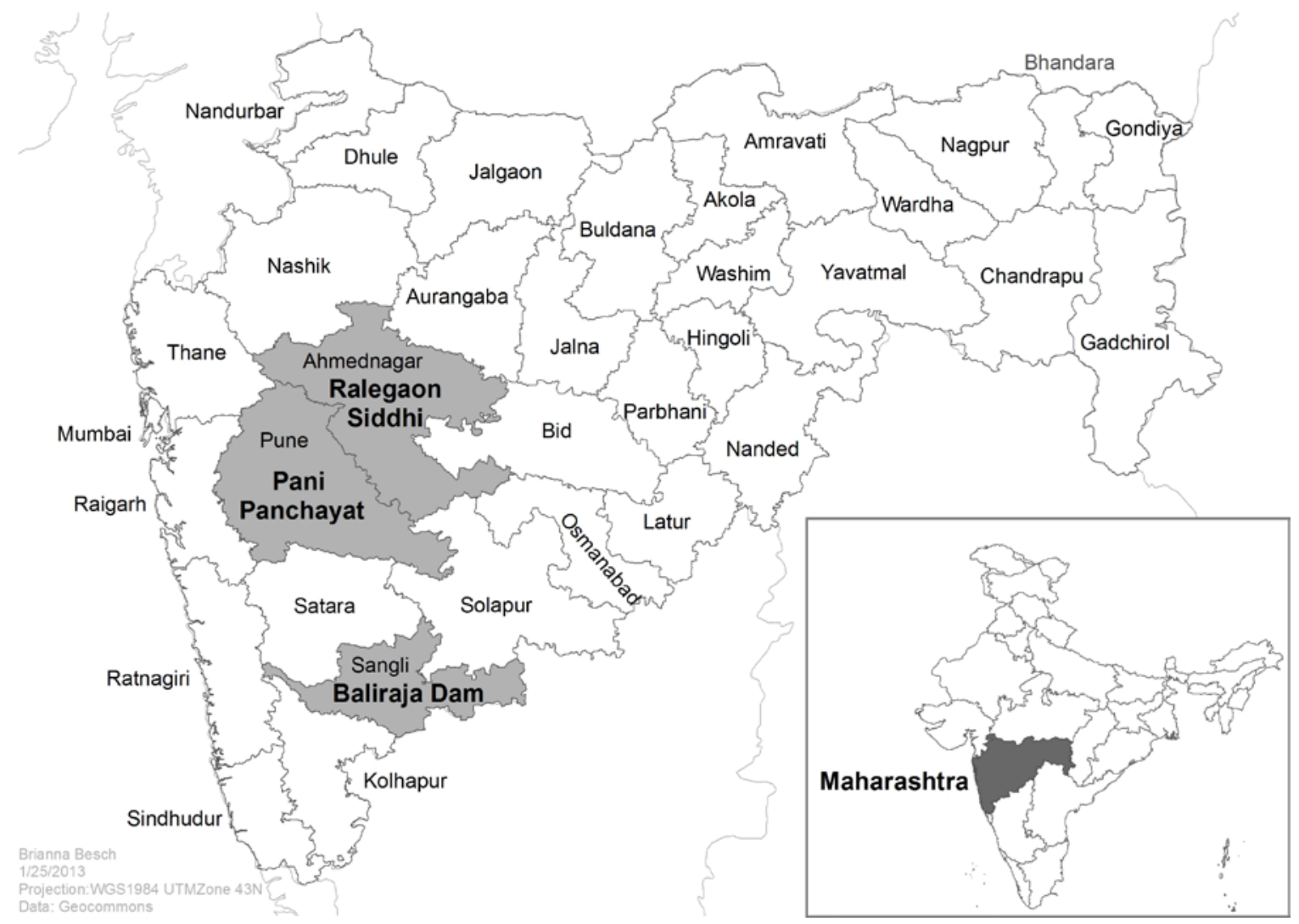

Figure 2: Location of Watershed Projects in Maharashtra.

The Salunkhe's efforts began when they left their urban home in Pune and leased a 16 acre (6.5 hectare) plot on a hillside in Naigon village to personally experiment with watershed development. On this land, they built a small home for themselves and their three children. They built contour bunds (tanks), cultivated fruit trees and built a percolation tank on the property. As a result of their efforts, produce increased from 10 quintals of grain to over 100 quintals (1,000 to 10,000 kg) on their plot in just two years (Pangare and Lokur 1996: 14). Their experiments also demonstrated that a half-acre of irrigated land, cropped with a diversity of grains and legumes, could provide enough food for a family for a year. Based on their experiences at turning a former wasteland into a productive and profitable landholding, they began working with a group of forty families from Naigon village to establish similar projects.

The first Pani Panchayat program evolved out of the Salunkhe's efforts in Naigon. The Pani Panchayat philosophy is based on the idea that water is a common property resource and that all members of a village 
society should have equal access to that resource regardless of caste, creed, class or gender. In Naigon village, families agreed to guide their cooperative efforts around five basic normative principles:

- Water is granted on the basis of a half acre (0.2ha) per person

- $\quad$ Irrigation is intended for seasonal water conserving crops (excluding sugarcane)

- $\quad$ Irrigation rights are extended to landless persons

- Water is held as an unalienable community right that is unattached to a parcel of land

- 20 percent of irrigation costs are borne by community members as cash contributions.

In addition to the above rules, the lift irrigation scheme was to be managed by a five-member committee, with a unanimously appointed Gat Pramukh (waterman) in charge of operations.

\begin{tabular}{|l|c|c|c|}
\hline & Pani Panchayat & Ralegaon Siddhi & Baliraja dam \\
\hline Increased water availability & $\mathrm{X}$ & $\mathrm{X}$ & $\mathrm{X}$ \\
\hline Improved ecological stability & $\mathrm{X}$ & $\mathrm{X}$ & $\mathrm{X}$ \\
\hline Increased income generation & $\mathrm{X}$ & $\mathrm{X}$ & $\mathrm{X}$ \\
\hline Improved women's welfare & $\mathrm{X}$ & $\mathrm{X}$ & $\mathrm{X}$ \\
\hline Improved lower caste welfare & $\mathrm{X}$ & $\mathrm{X}$ & $\mathrm{X}$ \\
\hline Built local technical capacity & $\mathrm{X}$ & $\mathrm{X}$ & \\
\hline Networked engineers \& farmers & $\mathrm{X}$ & $\mathrm{X}$ & \\
\hline Replication of NGO program & $\mathrm{X}$ & & \\
\hline
\end{tabular}

Table 2: Measured outcomes of watershed alternatives.

The Pani Panchayat experience transformed the village of Naigon. Seven Pani Panchayat schemes now serve ten thousand people in Naigon village, with one specifically for dalit (scheduled caste) families. In addition, four thousand trees have been planted in the village, including two thousand fruit trees. Farmers in the area now grow a variety of crops, including drought tolerant flowers for sale in Pune. Those who have taken up horticulture have seen their incomes significantly increase since the Pani Panchayats were established (Salunke et al. 1997: 302).

Based on their work in Naigon, the Gram Gaurav Pratisthan has helped other groups of farmers implement the Pani Panchayat model. In their collaborations with farmers, the Gram Gaurav Pratisthan stresses the importance of people's participation in the process of technical design. As Salunkhe et al. have written:

In order to make Pani Panchayat a true 'people's programme', Gram Gaurav Pratishtan assists only those farmers who approach the organization as a group to implement the scheme. The first contact is initiated by the group, and not the GGP. (2000: 192)

When the organization is approached by a group, they first get assurances from the farmers that they will accept the five Pani Panchayat principles. If the farmers agree, the group then selects a waterman to conduct a socio-economic survey of the members. After conducting this survey, Gram Gaurav Pratisthan staff visit the site intended for the irrigation scheme and perform a technical survey. With the help of farmers, they study water flows, possible lengths for pipelines and the overall command area of the scheme. Gram Gaurav Pratisthan technicians estimate the cost of the project and the amount of water available. After this information is presented to farmers, a plan is outlined and the financial obligation of each family is established. While the initial technical survey is paid for from farmer contributions, the NGO finances lift irrigation schemes through interest-free loans to farmers groups, as well as obtaining loans on their behalf from national agricultural banks.

Beginning with one project in 1972, the Pani Panchayat model is currently operative on 52 projects in 25 villages in Maharashtra. By 2000, Pani Panchayat schemes had brought over 3,000 acres (1,214 ha) of land under irrigation in Maharashtra, serving over 1,500 families (Salunkhe et al. 2000: 189). In several Pani Panchayat villages, including Mahur village, access to water has resulted in reverse migration trends where people are moving from cities back to their ancestral villages (Apte 2001). Beyond helping farmers design lift irrigation schemes, the NGO also operates a Watershed Training Center in the small city of Saswad where 
local youth are educated in civil engineering techniques. These efforts are financed through donations from members, international aid agencies, and a large contribution from the Salunkhe family. Regrettably, Vilasrao suffered a massive heart attack at his home in Pune, and passed away on April 23, 2002. A softspoken and gentle man, Salunkhe commanded respect from politicians, engineers and farmers alike for his achievements at promoting water equity. His vision is now being carried forward through Kalpana Salunkhe's leadership of the NGO.

In addition to Pani Panchayat efforts in Maharashtra, the model is being replicated in other regions of India. Before his untimely death, Vilasrao Salunkhe served as an official advisor to the Andra Pradesh Chief Minister's Water Conservation Mission. In this capacity, he was helping to design a government-sponsored version of the Pani Panchayat system in Khammam district to irrigate 900 hectares for 400 families. As part of these efforts, Vilasrao had been facilitating information exchanges by bringing Pani Panchayat farmers from Maharashtra villages to Khammam district in Andra Pradesh.

Pani Panchayat efforts have met a number of goals. In addition to increasing water availability and rural incomes, these projects have built local technical capacity by networking engineers and farmers together. There are still hurdles to overcome, especially the supply of reliable rural electricity to operate the lift irrigation. Yet, in terms of project replication, the Pani Panchayat concept has proliferated in Maharashtra, as well as in other states in India.

\section{Ralegaon Siddhi}

At the same time that the Salunkhe family was establishing Pani Panchayat schemes in Pune district, similar watershed efforts were underway to the northeast in Ahmednagar district. The village of Ralegaon Siddhi, located in drought prone Parner taluka in the central western plateau region of the district, gets on average 450 to 650 millimeters of annual rainfall. This region is more drought prone than Pune district to its southwest, where Pani Panchayat efforts unfolded. The topography in this area takes the form of small undulating hills that are offshoots of the Sahyadri range.

Before watershed development began in Ralegaon Siddhi, the roughly 2,000 residents relied on water by tanker truck from March through the beginning of the monsoon season in June. There was also less than one acre (0.4 ha) per family under irrigation in the entire village (Hazare et al. 1996). Because of low agricultural productivity, a large percentage of men migrated annually to urban areas in search of gainful employment. In 1974, one village resident, retired army general Anna Hazare, embarked on a development strategy to promote "growth with equity" (Awasthi and Panmand 1994: 20). Hazare mobilized villagers to renovate a dilapidated temple in the village center and repair the village water percolation tank. Eventually, Hazare's village revitalization efforts stretched to include many aspects of life in Ralegaon Siddhi, including water, agriculture, renewable energy, education, and women's empowerment.

With Hazare's leadership, Ralegaon Siddhi became one of the first villages in Maharashtra to experiment with the process of integrated watershed development. Through a Zilla Parishad (district council) initiative, and with the help of the Departments of Social Forestry and Soil Conservation, village volunteers first built small check dams throughout the watershed. In support of soil and water conservation measures, villagers also agreed to ban all tree felling and open animal grazing.

In total, four micro-watersheds have been developed in Ralegaon Siddhi using a "ridge to valley approach". Each micro-watershed was divided into three zones: the upper reach, the mid-reach and the lower reach. In the upper reaches, or the runoff zone of the watershed, brushwood dams, contour trenches, loose boulder dams, earthen dams, and gully plugs were constructed. In the mid-reach of the watershed, the recharge zone, villagers conducted land leveling and built terraces, contour bunds, farm ponds, and soil conservation structures. In the lower reaches, considered the water storage zone, villagers built small dams, percolation and village tanks, and sub-surface underground storages. In addition to these efforts, over 300,000 trees have been planted in Ralegaon Siddhi.

Unlike Pani Panchayat schemes, water distribution in Ralegaon Siddlhi is not based on a family quota. Instead, water equity was promoted through a rationing system. A benefit card is given to all landowners in the village. Benefits are calculated based on the total available irrigation water in the village. If there is enough water available to supply 70 percent of village land with irrigation, each landholder is assured that 70 percent of their land will receive water. Public lands and water shares are also provided to landless people to meet their domestic, fuel and fodder needs. It is stipulated in Ralegaon Siddhi that water shares cannot be sold.

The impact of watershed development is very visible in Ralegaon Siddhi. From an initial 56 acres (22.7 ha) of irrigated land in 1974, there were over 450 acres (182 ha) irrigated in the village by 2000 (Jal Sandharan 2000). Within just the first decade of watershed development, agricultural production increased in Ralegan Siddhi from 294 tons (267 tonnes, 1975-76) to 1,386 tons (1257 tonnes, 1985-86) (Awasthi and Panmand 1994: 43). The crop pattern has also significantly changed in the village. Farmers can now sow four seasons of crops, meeting the annual food needs of the community (Hazare et al. 1996: 9). In addition to the surface waters that are stored behind small dams and ponds, Ralegaon Siddhi villagers have also dug ten cooperative wells. These wells are governed by irrigation societies of approximately twenty farmers each. 
These cooperatives pool together funds to purchase and install drip irrigation. One other important result of watershed development has been that women no longer have to trek two to three kilometers for water. In their recent study, Mehta and Satpathy wrote that water is available within 100 meters of every home (Metha and Satpathy 2008: 24).

Based on their successes at participatory watershed development, villagers in Ralegaon Siddhi institutionalized a process of needs-based action research. Village development problems are first collected by stakeholders and prioritized. A range of participatory rural appraisal methods are utilized to plan a project, including transect walks and resource mapping. On the basis of this research, local stakeholders draw up an action plan and submit it to the village gram sabha (voting body). After a project receives approval, it is implemented by village volunteers. In Ralegaon Siddhi, village residents are required to perform two days of shramdan (volunteer labor) each month, with days allocated to each family based on the number of able bodied members (Hazare et al. 1996: 15).

In addition to soil and water conservation methods, the Ralegaon Siddhi integrated development approach includes strict social codes that guide development, including bans on alcohol, smoking and gambling. The process of village development extends beyond the fields to include educational facilities for children, women's credit circles, and commodity development programs, like dairy cooperatives. In recent years, the village has also installed several renewable energy projects, including solar street lights, each with a separate panel, four large community biogas plants linked to community toilets, and a wind turbine for pumping water.

Critics maintain that these results are non-replicable in other villages because of the vast financial expenditures that have supported efforts in Ralegaon Siddhi. Twenty years of watershed development have cost over one crore rupees (approximately US\$ 250,000). These projects have been financed by villagers (48\%), the Central Ministry (7\%) and the Government of Maharashtra (45\%) (Jalsandharan Department 2000). Support from the Government of Maharashtra has included contributions from the Maharashtra Drought Prone Areas Program, Desert Development Program, IWDP (Wasteland Development Program), and Zilla Parishad. In addition, the central government provided financing from the CAPART program at the rate of Rs. 4,000 per hectare (approximately US\$ 100 per hectare). Yet, this level of support was not afforded to Ralegaon Siddhi from the very beginning. Rather, early private investments by Hazare catalyzed subsequent public investments so results could be sustained and scaled.

These critiques did, however, spur Hazare to develop a program to replicate the Ralegaon experience elsewhere. In 1994, the Hind Swaraj Trust was established as a NGO to promote the achievements of Ralegaon Siddhi. A Watershed Training Center was founded in the village to provide technical education to local youth, NGO workers and government officials. The objectives of the training center are to promote economic development for both landowners and the landless. According to Mr. Pradeep Garole, Principal of the Training Center, watershed development relies on an interdisciplinary approach to technical expertise. The training program stresses that each watershed development project requires detailed research that includes socio-economic, agro-ecological, hydrological, engineering and geological surveys.

The Watershed Center receives support from the central government's CAPART program. CAPART finances the training of village level watershed development teams. Each team consists of an engineer, an agriculturalist, a social worker and a veterinarian. The team receives three months of training in all aspects of watershed development. By 2001, over 82 teams, working in twenty districts in Maharashtra, had been trained at Ralegaon Siddhi through this program. The center also hosted training programs for government officials, including 72 officials from the Karnataka Forest Department and 150 trainees from the Agriculture Department of the Western Ghats section. Between 1997-2009, over three hundred thousand visitors have participated in the center's activities.

The village of Ralegaon Siddhi has achieved some major development outcomes over the last thirty years. As was the case with Pani Panchayat efforts, watershed development in Ralegaon Siddhi has increased incomes, improved ecological sustainability and promoted greater participation in demand-side planning. These results include a 52\% increase in cropped area (Mehta and Satpathy 2008). The scale of activities, however, is noticeably different in Ralegaon Siddhi. While Pani Panchayat programs impact groups of farmers within a village, the Ralegaon Siddhi program has transformed the entire village. In addition, the Watershed Center at Ralegaon Siddhi has trained hundreds of NGO and government officials, from within and outside of Maharashtra, in the social and technical principles of the Ralegaon Siddhi model.

\section{Baliraja Dam}

At the same time as the Pani Panchayat and Ralegoan Siddhi efforts were ongoing in other districts of Maharashtra, the Baliraja dam was under construction on the banks of the Yerala River in Khanapur taluka in Sangli district. Sangli district is located in southern Maharashtra within the Krishna and Warna river valleys. Because of its close proximity to the Sahyadri range, annual rainfall averages in this district can range from 4,000 millimeters at nearby hill stations to 500 millimeters in the plateau region. Even where precipitation levels are high, inadequate water infrastructure makes it impossible to store significant monsoon rains. 
The Baliraja dam was built to serve the villages of Balawadi and Tandulwadi. In the early 1980s, 100 out of 122 wells had entirely dried up in these two villages (Thukral 1992: 148). In response to drought conditions, local activists from the Mukti Sanghrash Chaval (Struggle for Liberation Movement), began a political campaign to respond to the drought crisis with an alternative approach for irrigation development. Local science fairs were organized to survey village waterways, wells and irrigation facilities. Activists also investigated historical cropping patterns, local geological conditions and vegetation patterns. Based on their studies, in October 1985, a citizen-based Council for Drought Eradication was established by leaders from local activist organizations with representatives from both Balawadi and Tandulwadi villages. This Council decided that the local water shortage could be remedied through the construction of a "people's dam" - one designed and constructed by the local population (Phadke 2002).

Under the Council's direction, local activists approached a group of engineers to help with the design of the dam. The technical aspects of the dam were designed free of charge by $\mathrm{K}$. R. Datye and a team of engineers from his technology group, the Center for Applied Systems Analysis in Development (CASAD). CASAD was founded as an interdisciplinary research group by Datye in Mumbai in 1980. Datye began his career as a water engineer in the 1950s with the Central Water Commission. A self-described "subversive," Datye became disenchanted with a state approach to development that felt to him like "water imperialism." This term refers to the continuation of a colonial, large-scale infrastructure approach to project development aimed at cash crop cultivation. Datye took up research activities to formulate alternative dam and irrigation technologies. In addition to suggesting technical designs for dam projects, CASAD designers work with grassroots movements to examine how local agricultural integrity can be sustained through development projects. Alongside their work in the water sector, CASAD also actively promotes solar energy, alternative road building and improved housing materials and designs. Datye has stated that CASAD's uniqueness is based on their ability to make "economists think about social issues and technologists and scientists think about scarcity".

In the Baliraja case, CASAD designers not only suggested a design for the dam, they also addressed how soil fertility and local water tables could be restored. CASAD focused on harvesting rainfall in the local watershed first, and then looking to exogenous supplies. CASAD argued that while a minimum outside water source may be necessary to augment the local supply in a drought prone region, communities do have the ability and the best knowledge and experience to manage rainfall and groundwater supplies efficiently as long as they receive an assured minimum water supply.

CASAD's irrigation experts prepared design suggestions for the dam based on how much water each family needed for subsistence and profit-making activities. In 1986, CASAD began on-farm experiments. From 1986 through 1991, they worked with local farmers to test a diversity of subsistence crops and watering schedules. As a result of these trials, it was determined that food security for a family of five could be met with one acre of land supplied with 1,400 cubic meters of water (Joy 1992). They also established that local food security could be bolstered by diversifying crop production to include groundnuts (peanuts), vegetables, oil seed and chickpeas. The experiments also determined that organic inputs and increased tree cover would help improve soil moisture.

Based on CASAD's design recommendations, the village Drought Council decided to build a 4.5 meter tall and 120 meter wide dam across the Yerala River to enable protective irrigation and drinking water. The dam was to have a storage capacity of 20 million cubic feet $\left(566,000 \mathrm{~m}^{3}\right)$. Baliraja waters were intended irrigate 380 hectares and provide water to four hundred families. The dam was designed to be low cost, built with the extensive use of local and renewable materials, and be able to provide non-farm income to local workers (Joy 1992: 5).

The project was pioneering in terms of its construction, water delivery system and management regime. The dam was designed to be built in two stages. The first 2.5 meters are a conventional masonry dam. The second two meters use an innovative form of timber gates. These timber gates, along with a valve system at the base of the dam, are periodically opened during the monsoon rains to filter out accumulated silt. Conventional dam projects do not include such timber gates, and consequently often silt up after a brief period of use as soil erodes and ends up in the reservoir. Trees were also planted along the banks of the Yerala to provide erosion control. In addition to these trees, CASAD's plan suggested that one third of the land area in both villages be designated for reforestation to help increase soil moisture and soil retention.

Another innovative feature of the Baliraja dam was the use of a stage lift for water distribution. Water is usually lifted up to the highest contours of a benefit area and then distributed from that point by gravity. In the Baliraja case, water was lifted through a two stage system. First, water was lifted to a raised tank and some amounts dispersed locally. A small pump then lifted the remaining water for those families at a higher elevation. This system avoided the need for expensive pressure-proof pipes. The engineers developed and designed a unique form of a low-pressure flexible PVC pipe with ferro-cement cover that brought the price of piping down from an average Rs.400 (US\$13 based on 1990 figures) per meter to Rs.50 per meter (US\$2 based on 1990 figures) (Patankar n.d.: 5).

Water from the Baliraja dam is distributed by Pani Panchayat principles. K.R. Datye brought Vilasrao Salunkhe in as a consultant on the Baliraja's design. Water distribution for the Baliraja dam is governed by a water users cooperative. The cropping parameters and water norms are based on field experiments that were 
conducted by local farmers and CASAD from 1986-1991 (Joy 1992: 9). Each family is allotted a basic service of 1,400 cubic meters of water. The following rules govern water use (Thukral 1992: 152-153):

- $\quad$ Every member of the cooperative is entitled to a share regardless of gender or caste

- $\quad$ Each family's water supply depends on the number of family members, not on the size of its land holdings

- $\quad$ Landless members are entitled to shares that can be sold or used on leased land (A different principle than with the Pani Panchayat)

- Water is made available in bi-monthly stretches from June $1^{\text {st }}$ to January $15^{\text {th }}$ for protective irrigation of non-water intensive crops. From January $15^{\text {th }}$ to June $1^{\text {st }}$, water is reserved for drinking purposes.

The Baliraja dam was built after surmounting many government challenges. The dam's foundation stone was laid on January 25, 1987. After construction of the dam reached the height of one foot, the dam was pronounced illegal by the district Collector, who ordered suspension of all work. The local authorities questioned the villagers' legal rights to build a dam along the Yerala River. After six months of organized protest by local activists and farmers, the Government of Maharashtra agreed to hold discussions over the project. Sociologist Gail Omvedt has written that the notion of peasants building a dam went against the basic tenets of the clientelistic rural political system (Omvedt 1993). Development work was seen as the domain of bureaucratic experts and engineers, not local farmers and social workers. Despite attempts to delay construction, by order of the Supreme Court of Maharashtra, the Baliraja dam was approved on March 1988 based on a government committee's findings (Joy 1992: 7).

The first stage of the dam, the masonry construction, was completed in 1990. Due to a lack of project funds, the second stage, installation of the timber gates, has only been partially completed. Water is currently held behind the dam from June through January, a six month period directly following the monsoon. CASAD's reforestation plan, which intended to bring one third of the area under tree cover, has yet to be fully implemented. Though full water storage capacity in the small reservoir has not yet been achieved, one hundred families in Tandulwadi and a group of dalit families in Balawadi have been using Baliraja waters since 1990. Since construction of the Baliraja dam, water has been percolating through the soil and is recharging the water table. Villagers have seen a rise in their local water table, which means they can again lift drinking water from their wells throughout the year.

The Baliraja dam was built on the political organizing successes and watershed design experiences of both Pani Panchayat and Ralegaon Siddhi. The Baliraja dam has also extended the impacts of the Pani Panchayat model by focusing on water provision for two entire villages, as opposed to a small group of farmers. In addition, it has built on the Ralegaon Siddhi model by moving beyond local rainwater harvesting and soil conservation toward building a sophisticated dam structure. Yet, the impacts of the Baliraja project have not been as dramatic as either the Pani Panchayat or Ralegaon Siddhi efforts. Because the project remains incomplete due to a lack of financial resources, its full potential for raising incomes has not been realized.

The engineers and activists affiliated with the building of the Baliraja dam never intended to replicate the project as a technical model. Rather, they saw it as an example of effective social networking. K.J. Joy, a watershed activist associated with the dam, has argued that their main goal was to create alternative paradigms for water access and irrigation policy. According to Joy (1992), "The Baliraja is one step toward this change. The most important contribution of the Baliraja was that it established that people are ready to share water and that people can form their own organizations to redistribute water and to manage it". The project demonstrated that collaborative research programs that connect activists, scientists, and farmers can promote participatory technology development and sustainable livelihoods.

\section{Equity, technology and praxis}

The three cases outlined above, Pani Panchayat, Ralegaon Siddhi and the Baliraja dam, are well known in Indian academic and activist circles for their important technical and social contributions toward a vision of integrated watershed development. There are important collective lessons that can be learned from these cases about technology design, participatory development and the promise of social equity. The most important lesson pertains to how water infrastructure projects can be reclaimed in ways that embed new social and political values into technological design. As such, they reflect the maturation of watershed development in India.

Under a linear innovation chain model, technologies are designed in the laboratory, tested in the field and then diffused to users. The watershed development models described in these three cases inverted this approach by involving users in the design of technologies from the outset. In the process of adapting practice to place, the overarching goal of these projects was to extend water access to as many people as possible, irrespective of gender and landholding status. Yet, in each of these cases, equity and agro-ecological sustainability operated under different definitions and community constraints. 
In the case of Pani Panchayat schemes, water equity is defined in terms of an equal provision of water per family, regardless of land holding size. Irrigation is intended only for water conserving crops, with the total exclusion of sugarcane which is the chief agricultural commodity of the region. Based on these criteria, members of the Pani Panchayat are involved in all aspects of technical design and benefit equally from the project. Lift irrigation schemes are designed to raise water to the level of a percolation tank, from which water is pumped in rotation to each family plot. Since the irrigation project is intended to promote ecological regeneration, as well as income security, the projects are designed to conserve the volume of water stored in percolation tanks and utilized by farmers. In theory, this allows adequate supplies to remain for aquifer recharge.

In Ralegaon Siddhi, water equity is promoted through a benefit sharing system. Every landowner is allowed to irrigate the same percentage of their fields. To ensure that every villager has access to water supplies, the village is divided into four micro-watersheds. Each micro-watershed has a range of soil and water conservation structures, which store runoff in decentralized dams and ponds throughout the village. When a new technical project is being developed in Ralegaon Siddhi it must undergo a study of social, economic and environmental feasibility. Finally, the project must receive approval from the gram sabha (village assembly) before it can begin.

Lastly, the Baliraja dam builds on lessons from Pani Panchayat experiments in equitable water distribution. The project was designed not only to store water, but also to promote food security, crop diversity and increased tree cover. However, unlike both Pani Panchayat and Ralegaon Siddhi, the Baliraja project did not utilize government funds or build on a pre-existing government project. In addition to their agroecological goals, the dam's designers hoped to deliver a strong political statement through the construction of this dam. The dam was intended to demonstrate that village communities can drive technical development, through their experiential knowledge and self-determined needs. While it is still incomplete, with the last gates still to be installed almost two decades later, the project has made its political mark by challenging the state's approach to expert driven, top-down irrigation development (Phadke 2002).

There is little disagreement that technological artifacts are both a response to and an outcome of social and political processes. The crucial issue is how technological choices produce and resolve conflicts over social and political values. These cases point to the necessity for intermediary institutions, such as NGOs, to network among and between civil society, state agencies and community based stakeholders. As an earlier section of this article discussed, over the last two decades NGOs have emerged as critical actors in watershed development (Farrington et al. 1999). Compared to government agencies, NGOs are considered to be more decentralized, accountable and context driven institutions (Kolavalli and Kerr 2002). Scholars have also argued that NGOs have general organizational attributes that make them good implementers of participation, such as local staff, limited geographical focus, and smaller portfolios of projects compared to state agencies. These institutions are also expected to help replicate and "scale up" local experiments over a broader region.

Yet, the pendulum has swung so far in favor of NGOs that new Indian government watershed development guidelines designate NGOs as the main implementing agencies for government financed projects. The over-reliance on non-governmental institutions is problematic because there is a great deal of breadth in quality and capacity across the NGO sector. Some NGOs have technical staff and receive government funding, while others are self-supporting and more anti-establishment. Against previously held beliefs, recent research has also shown that NGOs are not good at scaling up public participation in watershed efforts (Kolavalli and Kerr 2002). When NGOs become development administrators, they often lose their ability to focus on the macro policy scale. Furthermore, when a single NGO is charged with overseeing the implementation of multiple projects, its approach can become as "model"-driven as any government agency, losing focus on the importance of context and demand-driven development. Part of the problem is that "scaling up" participation is not just about "technique"; it often requires radical internal organizational changes.

The three cases analyzed in this article describe the role intermediary NGOs play in not just scaling up development projects but in catalyzing learning networks so that technological designs are rooted to place and project scales can be matched to local needs. It is this approach to social networking, and the design of alternative technological pathways, that is the most important lesson to take away from the Maharashtra example. While watershed development efforts have not transformed the entire nation, these programs have had measureable impacts on people's lives in specific places. It is within these niches of social activism and technological pluralism where we can locate ecologies of hope (Rajan and Duncan 2013).

\section{Resonances}

This article has described how watershed development first emerged in India as a response to a colonial and post-colonial engineering paradigm that privileged giant infrastructure to move water across vast regions with little concern for the social and ecological devastation left in the wake. Today, the overarching goal of watershed development must be to solve physical scarcities while addressing the patterns of social and economic vulnerability that go hand in hand in lived-in landscapes. Scholars of environment and society can take away important lessons from thirty years of watershed development experience and experiments in India. These efforts contribute new theoretical and empirical understandings about the politics of 
participation and provide practical models that articulate how water can be provisioned for those who need it, when they need it most.

Watershed development in India can also be understood as the merging of two powerful environmental narratives (Mosse 2003). On the one hand, a strong activist critique of the development state, advanced by anti-dam movements and NGOs like the Centre for Science and the Environment, has asserted a temporal narrative about environmental change that declares an equilibrium past, colonial decay and now celebrated recovery of knowledge and power over water. On the other hand, "Washington Consensus" policy reform principles, endorsed by governments and bilateral and multilateral donors, has ushered in the era of devolved power, decentralized management and a reduced role for the state in public works projects. In the space between these two narratives, one focused on recovering citizen power and the other on absolving state responsibility, we can connect directly with Karl Polanyi's articulation of the "double movement" in society.

These stories of participatory development demonstrate how enduring and resilient institutions are built from the ground up. Resonating with other water cases across Asia, such as Stephen Lansing's work on Balinese water temples (Lansing 1991) and Mark Baker's examination of kuhl irrigation in the Kangra Valley of India (Baker 2005), these technological systems represent the kind of flexible engineering that withstands social shocks and political transigence. The dystopian literature on water scarcity in India, described in the introductory section of this article, often fails to pay adequate attention, or give due credit, to the efforts of the many dedicated officials, activists and engineers that have produced some watershed development successes. In reality, environmental protection, equitable resource provision and enduring institutions are emerging from the dogged on-the-ground experiments that reconnect the meanings and value of land, water, and livelihoods.

Echoing the other themes and cases in this special section, watershed development is deeply connected with fair trade coffee networks, land redistribution efforts, energy planning and agricultural modification. In each case, communities of innovators came together to organize themselves around a new vision of sustainable livelihoods (Rajan and Duncan 2013). Whether the case study is located in the state of Maharashtra or California, these social movements are fundamentally challenging the role of "expert" knowledge and authority in projecting technological futures. The production and dissemination of community-based research enables everyday citizens to produce alternate visions of landscape and memory that can dislodge power where it comfortably rests.

\section{References}

Agarwal, A. and S. Narain (eds). 1997. Dying wisdom: the rise, fall and potential of India's traditional water harvesting systems. New Delhi: Center for Science and the Environment.

Apte, T. 2001. Participatory watershed management in a drought-prone area of Maharashtra. Paper for Kalpavriksh-Lokayan Programme, Conflicts over natural resources and their resolutions. Pune: Kalpavriksh.

Awasthi, R. and D.K. Panmand. 1994. Ralegan Siddhi: a model for village development. Bombay: Foundation for Research in Community Health.

Attwood, D.W. 1992. Raising cane: the political economy of sugar in western India. Boulder: Westview Press and New Delhi: Oxford University Press.

Baker, M. J. 2005. The kuhls of kangra: community-managed irrigation in the western Himalaya. Seattle: University of Washington Press.

Bavikar, A (ed.). 2007. Waterscapes: the cultural politics of a natural resource. New Delhi: Permanent Black.

Baviskar, A. 1995. In the belly of the river: tribal conflicts over development in the Narmada Valley. Delhi: Oxford University Press.

Bhat, K.V. and S. Satish. 1993. NGO links with the Karnataka state watershed development cell. In J. Farrington and D. Lewis (eds.), NGOs and the state in Asia. New York: Routledge Press.

Chambers, R. and G. Conway. 1991. Sustainable rural livelihoods: practical concepts for the 21st century. Discussion Paper 296. Sussex: IDS.

Chhotray, V. 2004. The negation of politics in participatory development projects, Kurnool, Andra Pradesh. Development and Change 35(2): 327-352.

Farrington, J., Turton, C. and A.J. James (eds). 1999. Participatory watershed development: challenges for the twenty-first century. New Delhi: Oxford University Press.

Gleick, P. 2009. The world's water. Oakland: The Pacific Institute.

Gilmartin, D. 1994. Scientific empire and imperial science: colonialism and irrigation technology in the Indus basin. The Journal of Asian Studies 53 (4): 1127-1149.

Goldman, M. 2005. Imperial nature: The World Bank and struggles for social justice in the age of globalization. New Haven: Yale University Press. 
Hazare, A.,G. Pangare and V. Lokur-Pangare. 1996. Adarsh Gaon Yojana government participation in a people's programme (Ideal Village Programme of the government of Maharashtra). Pune: Hind Swaraj Trust.

Headrick, D. 1988. The tentacles of progress: technology transfer in the age of imperialism. Delhi: Oxford University Press.

Hinchcliffe, F., J.Thompson, J. Pretty, I. Guijt and P. Shah. 1999. Fertile ground: the impacts of participatory watershed management, London: IT Publications.

Jeffery, R. and N. Sundar (eds). 1999. A new moral economy for India's forests? Discourses of community and participation. New Delhi: Sage Publications.

Joy, K. J. 1992. People managed irrigation systems: a case study of Bali Raja Dam. Paper presented at the National Workshop on "Farmer Management in Indian Irrigation Systems," Administrative Staff College of India, Hyderabad, February 4-6, 1992.

Kale, V.S. and S. N. Rajaguru. 1988. Morphology and denudation chronology of the coastal and upland river basins of Western Deccan Trappean landscape (India): a collation. Zeitschrift für Geomorphologie 32 (3): 311-327.

Kerr, J. 2002a. Sharing the benefits of watershed management in Sukhomajri, India. in S. Pagiola, J. Bishop and N. Landell-Mills (eds.), Selling forest environmental services. London: Earthscan.

Kerr, J. 2002b. Watershed development, environmental services and poverty alleviation in India. World Development 30 (8): 1387-1400.

Kerr, J., G. Pangare and V. Lokur-Pangare. 2002. Watershed development projects in India: an evaluation. Research Report 127. Washington, DC: International Food Policy Research Institute (IFPRI).

Khor, M. and L.L. Lin. 2002. Good practices and innovative experiences in the South: citizen initiatives. London: Zed Books.

Kolavalli, S. and J. Kerr. 2002. Scaling-up participatory watershed development in India. Development and Change 33(2):213-235.

Lansing, S. J. 1991. Priests and programmers: technologies of power in the engineered landscape of Bali. Princeton: Princeton University Press.

Marothia, D. 2002. Institutionalizing common pool resources. New Delhi: Concept Publishing Co.

Mathur, K. and N. G. Jayal. 1993. Drought, policy and politics: the need for a long-term perspective. New Delhi: Sage Publications.

Mehta, L. 2005. The politics and poetics of water. New Delhi: Orient Longman Press.

Mehta, A. and T. Satpathy. 2008. Escaping poverty: the Ralegan Siddhi case. Working Paper No. 119. New Delhi: Chronic Poverty Research Centre, Indian Institute of Public Administration.

Meinzen-Dick, R. and M. Zwarteveen. 1998. Gendered participation in water management: Issues and illustrations from water users associations in South Asia. Agriculture and Human Values 15 (4): 337 345.

Ministry of Rural Development. 2006. From Hariyali to Neeranchal. Report of the Technical Committee on watershed programmes in India. Prepared by the Department of Land Resources. New Delhi: Government of India.

Moench, M., E. Caspari and A. Dixit (eds). 1999. Rethinking the mosaic: investigations into local water management. Kathmandu: Nepal Water Conservation Foundation and the Institute for Social and Environmental Transition, Boulder, Colorado.

Mollinga, P.P. (ed). 2000. Water for food and rural development. New Delhi: Sage Publications.

Mosse, D. 2003. The rule of water: statecraft, ecology and collective action in South India. New Delhi: Oxford University Press.

Ninan, K.N. 1998. An assessment of European-aided watershed development projects in India. Copenhagen: Centre for Development Research.

Omvedt. G. 1993. Reinventing Revolution: New Social Movements and the Socialist Tradition in India. Armonk, NY: M.E. Sharpe.

Pai, R. and S. Datta (eds). 2006. Measuring milestones: proceedings of the national workshop on Joint Forest Management (JFM). New Delhi: Ministry of Environment and Forests and Winrock International.

Pangare, G. The good society: the Pani Panchayat model of sustainable water management. New Delhi: Indian National Trust for Art and Cultural Heritage.

Patankar, B. No date. Water and land management in Krishna Valley and sustainable environment. Unpublished paper.

Phadke, R. 2002. Assessing water scarcity and watershed development in Maharashtra, India: a case study of the Baliraja Memorial dam. Science, Technology and Human Values 27 (2): 236-261. 
Ramamurthy, P. 1997. Rural women and irrigation: patriarchy, class and the modern state in South India. In C. Sachs (ed.). Women working the environment. New York: Taylor and Francis.

Rangachari, R., N. Sengupta, R. Iyer, P. Baneri and S. Singh. 2000. Large dams: India's experience. Capetown, South Africa: World Commission on Dams.

Rajan S.R. and C.A.M. Duncan. 2013. Ecologies of Hope: environment, technology and habitation - case studies from the intervenient middle. Journal of Political Ecology 20:70-79.

Rangan, H. 2000. Of myth and movements: rewriting Chipko into Himalayan history. London: Verso Press.

Reddy, V.R., M. Gopinath Reddy, S. Galab, J. Soussan, O. Springate-Baginski. 2004. Participatory watershed development in India: can it sustain rural livelihoods? Development and Change 35(2): 297-326.

Seeley, J., Batra, M. and M. Sarin. 2000. Women's participation in watershed development in India. Gatekeeper Series No. 92. London: IIED.

Sengupta, S. 2006. In teeming India, water crisis means dry pipes and foul sludge. New York Times. Sept 26, 2006. Page A1.

Shah, T. and K.V. Raju. 2001. Rethinking rehabilitation: socio-ecology of tanks in Rajasthan, Northwest India. Water Policy 3(2001): 521-536.

Sivaramakrishnan, K. 2002. Forest co-management as science and democracy in West Bengal, India. Environmental Values 11 (3): 277-302.

Specter, M. 2006. The last drop: confronting the possibility of a global catastrophe. New Yorker Magazine. October 23: 61-71.

Srivastava, A. and J. Chundi (eds.). 1999. Watershed management: key to sustainable development. Proceedings of a workshop on 'watershed management: towards unified participatory approach' held at Indian Social Institute, New Delhi. January 21-22, 1999. New Delhi: Indian Social Institute.

Thukral, E. G. 1992. Big dams, displaced people: rivers of sorrow, rivers of change. New Delhi: Sage Publications.

Turton, C., M. Warner and B. Groom. 1998. Scaling up participatory watershed development in India: a review of the literature. AGREN Network Paper No. 86. London: Overseas Development Institute.

UN-Inter Agency Working Group on Water and Environmental Sanitation. 1998. Johad: Watershed in Alwar District Rajasthan. Best Practices Paper Series.

Vania, F. and B. Taneja. 2004. People, policy, participation: making watershed management work in India. London: IIED.

van Koppen, B. 2000. From bucket to basin: managing river basins to alleviate water deprivation. Colombo: International Water Management Institute.

Wade, R. 1988. Village republics: economics condition for collective action. Cambridge: Cambridge University Press.

Whitcombe, E. 1972. Agrarian conditions in northern India: Volume I, the United Provinces under British Rule, 1860-1900. Berkeley: University of California Press. 


\begin{abstract}
India's water problems have long been portrayed by the international media as crises of poverty, desperation and corruption. Drawing an analogy to the "peak oil" discourse, "peak water" adherents express an impending dystopia through images of overpumped aquifers in the world's breadbasket regions, excessive irrigation that is rapidly depleting rivers and deltas, neglected pollutants that are poisoning return water flows. This focus on global water scarcities overshadows the real gains in water governance that have been achieved at local and regional scales. This is particularly true in India, where over the last three decades watershed development has significantly matured as a concept, method and technology for improving livelihoods. This article describes a set of empirical cases from the region of Maharashtra that define and demonstrate how watershed development is working to meet vital ecological and socio-economic goals. The focus is on how one particular social movement is tackling the most vexing issues faced by watershed planners: equity and landlessness.
\end{abstract}

Key words: participatory watershed development, Maharashtra, social justice, ecologies of hope, India.

\title{
Résumé
}

Les problèmes d'eau indiens ont longtemps été décrit par les médias internationaux comme une crise de la pauvreté, le désespoir ou la corruption. Faisant une analogie avec le discours "pic pétrolier», les croyants de «l'eau pic» exprimer une dystopie imminente à travers des images d'aquifères surexploités dans les régions les plus productives du monde, l'irrigation excessive qui épuise les fleuves et les deltas rapidement, et les polluants qui empoisonnent des écoulements d'eau. Cet accent éclipse les gains réels en matière de gouvernance de l'eau qui ont été obtenus à des échelles locales et régionales. Cela est particulièrement vrai en Inde, où l'aménagement des bassins versants a considérablement mûri en tant que concept, la méthode et la technologie pour améliorer les moyens de subsistance au fil des trois dernières décennies. Cet article décrit un ensemble de cas empiriques de la région de Maharashtra qui définissent et démontrer comment le développement des bassins versants répondre aux objectifs vitaux écologiques et socio-économique. L'accent est mis sur la manière dont un mouvement social aborde les questions les plus délicates rencontrées par les planificateurs des bassins versants: les inégalités et le manque de terres.

Mots clés: développement participatif des bassins versants, Maharashtra, la justice sociale, écologie de l'espoir, de l'Inde.

\section{Resumen}

Los problemas del agua en India se han representado en los medios de comunicación internacionales como crisis de pobreza, desesperación y corrupción. Estableciendo una analogía con el discurso del "petróleo pico", los seguidores del "agua pico" articulan una inminente distopía mediante imágenes de acuíferos sobreexplotados en zonas del mundo productoras de grano, irrigación excesiva que está acabando rápidamente con ríos y deltas o contaminantes olvidados que están envenenando el agua que vuelve a los ríos tras la irrigación. Este énfasis en la escasez global de agua eclipsa las mejoras reales en gobernabilidad del agua que se han conseguido a nivel local y regional. Esto es particularmente cierto para India, donde en las últimas tres décadas la gestión del agua se ha desarrollado significativamente como concepto, método y tecnología para mejorar la calidad de vida. Este artículo describe una serie de casos empíricos de la región de Maharashtra, los cuales definen y demuestran cómo la gestión del agua logra alcanzar objetivos vitales ecológicos y socioeconómicos. El énfasis se sitúa en cómo un movimiento social en especial está enfrentándose a los asuntos más complicados con que se enfrentan quienes planifican lo recursos acuáticos: la equidad y el problema de carencia de tierra.

Palabras clave: desarrollo participativo de cuencas hidrográficas, Maharashtra, la justicia social, la ecología de la esperanza, la India. 